\title{
STATUS OF PLASMA ELECTROLYTES, UREA, CREATININE, AND C-REACTIVE PROTEIN IN CANCER PATIENTS
}

\section{OLUBUNMI C OJO*, MODUPE F ASAOLU, AJIBADE O OYEYEMI, IBIKUNLE AKINLUA, OLORUNFEMI R MOLEHIN, OLUFISAYO G OYEBANJI}

Department of Biochemistry, Faculty of Science, Ekiti State University Ado-Ekiti, P.M.B. 5363 Ado-Ekiti, Nigeria. Email: talk2ojooc@gmail.com

Received: 27 July 2017, Revised and Accepted: 16 September 2017

\section{ABSTRACT}

Objective: Cancer is a major health problem not only in developed countries but also in developing countries like Nigeria. This study was designed to study the status of plasma electrolytes, urea, creatinine, and C-reative proteins (CRPs) in freshly diagnosed cancer patients.

Methods: Plasma electrolytes (sodium $\left[\mathrm{Na}^{+}\right]$, potassium $\left[\mathrm{K}^{+}\right]$, chlorine $\left[\mathrm{Cl}^{-}\right]$, and bicarbonate $\left[\mathrm{HCO}_{3}^{-}\right]$), urea, creatinine, and $\mathrm{CRP}^{-}$were estimated in four different types of cancer (liver, colon, cervical, and uterine) patients attending Ekiti State University Teaching Hospital Ado Ekiti Nigeria. A total of 250 patients (between age of 45 and 70 years) consisting of 50 patients in each cancer type and 50 normal subjects as control were considered in this study.

Results: The result obtained revealed a significant $(\mathrm{p}<0.05)$ increase in the plasma levels of $\mathrm{Na}^{+}, \mathrm{Cl}^{-}$, creatinine, and $\mathrm{CRP}$ in all the cancer types when compared with the control subjects. Plasma urea level decreased significantly in patients with colon (3.16 $\pm 0.70 \mathrm{mmol} / \mathrm{L}$ ) and liver ( $3.03 \pm 1.75 \mathrm{mmol} / \mathrm{L}$ ) cancer when compared with the control subjects $(4.80 \pm 1.12 \mathrm{mmol} / \mathrm{L}) . \mathrm{K}^{+}$and $\mathrm{HCO}_{3}$ - level was not significantly (p>0.05) different in all cancer types when compared with the control subjects.

Conclusion: This study revealed a possible link between plasma electrolytes, creatinine, CRP, urea, and cancer which could be useful in the assessment and management of cancer.

Keywords: Electrolytes, Urea, Creatinine, C-reactive protein, Cancer.

(C) 2018 The Authors. Published by Innovare Academic Sciences Pvt Ltd. This is an open access article under the CC BY license (http://creativecommons. org/licenses/by/4. 0/) DOI: http://dx.doi.org/10.22159/ajpcr.2018.v11i1.22033

\section{INTRODUCTION}

Cancer has become a major source of morbidity and mortality globally. In 2008, there were 12.7 million new cases and 7.6 million cancerrelated deaths [1]. Most, $56 \%$ of these newly reported cancer cases occurred in developing countries, and it is projected that, by $2030,70 \%$ of all new cases of cancer will be found in developing countries [2]. The reason behind this increase is due to population growth and increased life expectancy [3]. Some 100,000 new cases of cancer occur every year in Nigeria with high case fatality ratio with approximately $20 \%$ of the population of Africa and slightly more than half the population of West Africa, Nigeria, contributed $15 \%$ to the estimated 681,000 new cases of cancer that occurred in Africa in 2008 [1,4].

Cancer is characterized by loss of control of cellular growth and development leading to excessive proliferation and spread of cells known medically as malignant neoplasm [5,6]. Determining what causes cancer is complex. Many factors are known to increase the risk of cancer including tobacco use, certain infections, radiation, and lack of physical activity, obesity, and environmental pollutants [7-9].

Plasma electrolyte concentrations are among the most commonly used laboratory tests by clinicians for assessment of a patient's clinical conditions and disease status [8]. In physiology, the primary ions of the electrolytes are sodium $\left(\mathrm{Na}^{+}\right)$, potassium $\left(\mathrm{K}^{+}\right)$, calcium $\left(\mathrm{Ca}^{2+}\right)$, chloride $\left(\mathrm{Cl}^{-}\right)$, hydrogen phosphate $\left(\mathrm{HPO}_{4}{ }^{2-}\right)$, and hydrogen carbonate $\left(\mathrm{HCO}_{3}^{-}\right)[10,11]$. Electrolyte disorders are commonly encountered in the patient with cancer. In most cases, these disorders are associated with etiologies seen in all types of patients and are not specifically linked to the malignancy or its therapy (for example, diuretic-induced hyponatremia or hypokalemia $[10,12,13]$. The careful monitoring of the serum electrolytes plays very important role in the prognosis of diseases. Thus, proper recognition and treatment of these disorders is important in the overall care of the patient with cancer $[6,11]$. Likewise, the assessment of kidney functions tests (urea and creatinine) plays a key role in the diagnosis and management of cancer diseases as any deterioration of renal function results in elevations of these parameters in the blood. Elevated urea and creatinine levels in the blood signify impaired kidney function or kidney disease parenthesis [14-15].

C-reative proteins (CRPs) are a protein that is found in the blood. The level of CRP rises as a response to inflammation. Its physiological role is to bind to phosphocholine expressed on the surface of dead or dying cells (and some types of bacteria) to activate the complement system through the carrier complex [16]. CRP is synthesized by the liver in response to factors released by macrophages and fat cells (adipocyte) [17]. Many studies have shown that CRP has been implicated in the process of carcinogenesis $[18,19]$. Several metabolic changes occur in cancer development, and electrolyte imbalance is one of them. The electrolyte imbalance in advanced cancer patients can be induced by various factors. Furthermore, the kidney function parameters (urea and creatinine) and CRP are also important diagnostic markers implicated in the process of cancer development. Hence, the careful monitoring of these biochemical parameters plays a crucial role in the prognosis of this disease. However, there is a dearth of information on some of these biochemical parameters in cancer diagnosis cases. Therefore, this study evaluates the plasma levels of electrolytes, urea, creatinine, and CRP in four different freshly diagnosed types of cancer patients, namely, liver, colon, cervical, and uterine cancer with a view to provide useful information on the diagnosis and proper maintenance of patients already diagnosed with the disease. 


\section{METHODS}

A total number of 250 patients were involved in this study, 50 patients each for cervical, liver, uterine, and colon cancer, respectively, and 50 patients without cancer as control subjects. $5 \mathrm{ml}$ of venous blood were collected from each cancer patients and normal subjects. The collected blood samples were dispensed into lithium heparin bottles and were centrifuged at 10,000 rpm $(10,000 \mathrm{rpm})$ for $10 \mathrm{~min}$ and separated to obtain plasma. The separated plasma was stored at $-10^{\circ} \mathrm{C}$ for further analysis. Urea levels in plasma were estimated using the method described by Weatherburn [20]. Creatinine levels were determined using the method of Bartels et al. [21]. Plasma levels of electrolytes, namely, $\mathrm{Na}^{+}, \mathrm{K}^{+}$, and $\mathrm{Cl}^{-}$were carried out by flame photometry technique, using Gallenkamp flame photometer [22], while bicarbonate $\left(\mathrm{HCO}_{3}^{-}\right)$was analyzed using titrimetric method [23]. Plasma CRP was assayed using ELISA method as described by Deraz et al. [24]. All patients gave their informed consent, and this study was approved by the Institutional Review Board of the Hospitals.

\section{Data analysis}

Data gotten from the present study were presented as a mean value \pm standard deviation. The results were analyzed using the Statistical Package for Social Science (SPSS) version 16.0 (SPSS, Chicago, USA). A $p<0.05$ was considered statistically significant.

\section{RESULTS}

Table 1 revealed a significantincrease $(\mathrm{p}<0.05)$ in the mean plasma levels of $\mathrm{Na}$ in liver $(141.78 \pm 4.57 \mathrm{mmol} / \mathrm{L})$, colon $(144.13 \pm 4.16 \mathrm{mmol} / \mathrm{L})$, cervical $(143.35 \pm 3.37 \mathrm{mmol} / \mathrm{L})$, and uterine cancer $(143.25 \pm 2.37)$ patients when compared to the control subjects $(133.50 \pm 3.02)$; $\mathrm{Cl}^{-}$in liver $(102.72 \pm 3.10 \mathrm{mmol} / \mathrm{L})$, colon $(101.64 \pm 2.37 \mathrm{mmol} / \mathrm{L})$, cervical $(102.89 \pm 4.67 \mathrm{mmol} / \mathrm{L})$, and uterine cancer $(101.85 \pm 1.89 \mathrm{mmol} / \mathrm{L})$ when compared to the control $(97.7 \pm 1.32 \mathrm{mmol} / \mathrm{L})$ subjects. However, there was no significant difference $(p>0.05)$ in the mean plasma levels of both $\mathrm{K}^{+}$and $\mathrm{HCO}_{3}{ }^{-}$in all the cancer types when compared to the control subjects.

\section{DISCUSSION}

Cancer harms the body when damaged cells divide uncontrollably to form lumps or masses of tissue called tumors. Tumors can grow and interfere with the digestive, nervous, and circulatory systems, and they can release hormones that alter body function [7,11]. Table 1 shows that plasma sodium level was found to be higher in all the cancer patients considered. This condition also known as hypernatremia occur whenever free water loses exceed sodium loses. This may be attributable to excessive insensible loses with an impaired thirst mechanism [25]. The increase in plasma sodium level observed in patients with colon cancer might be due to a decrease fluid intake [25]. Milde et al. [26] also reported that high plasma sodium may be associated with tumors that invade the lateral hypothalamus, the tumors which may destroy the thirst center with the subsequent development of severe dehydration and hypernatremia.

CRP is an important marker of inflammation which is known to be involved in the initiation and progression of cancer. This could probably be the reason why elevated level of CRP (Fig. 1) was observed in all the cancer patients considered in this study. Our observations are similar to those reported by Falconer et al. [27]. A significant $(\mathrm{p}<0.05)$ increase was also observed in the plasma level of creatinine (Fig. 2) in all the cancer types when compared with the normal subjects. In contrast, the urea level was significantly low in most of the cancer patients, especially colon and liver cancer. Plasma creatinine and urea are the major parameters to access renal function and excretion of these components is the function of lean body mass in normal person. Plasma concentration of creatinine and urea could be used as an indicator of nephrotoxicity [28]. High creatinine level was also observed in cervical cancer by Koji et al. [29] who concluded that elevation of plasma creatinine level was the most significant risk factor for cervical cancer.

Furthermore, low urea level was observed in colon cancer patients in a study by Christy [30]. However, the frequency of cancer, and especially of colon cancer, may increase greatly if urea levels are low. A favorable nitrogen economy depends on the ability of an organism to regulate the synthetic and catabolic processes involving numerous and different proteins with the goal of maintaining a relatively constant body protein mass. In the presence of cancer, the homeostasis of nitrogen is disturbed

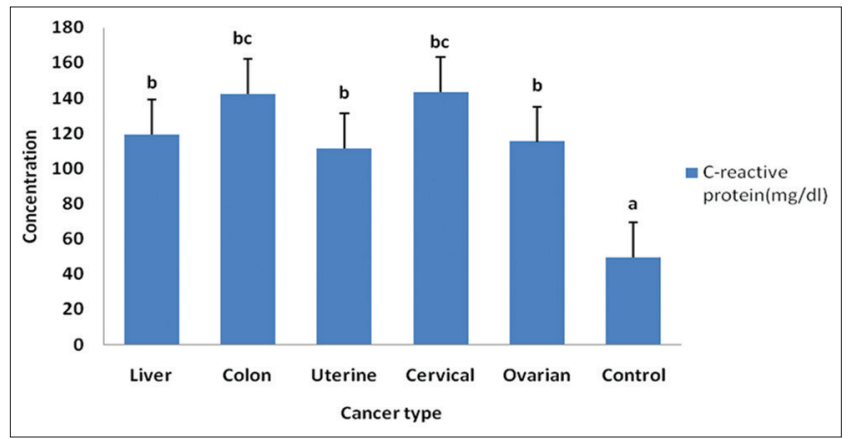

Fig. 1: Concentration of C-reactive protein in the plasma of cancer patients and control subjects. Results were expressed as means \pm standard deviation, $(n=50)$ graphs of the same parameter with different data labels indicate significant difference at $\mathbf{p}<0.05$

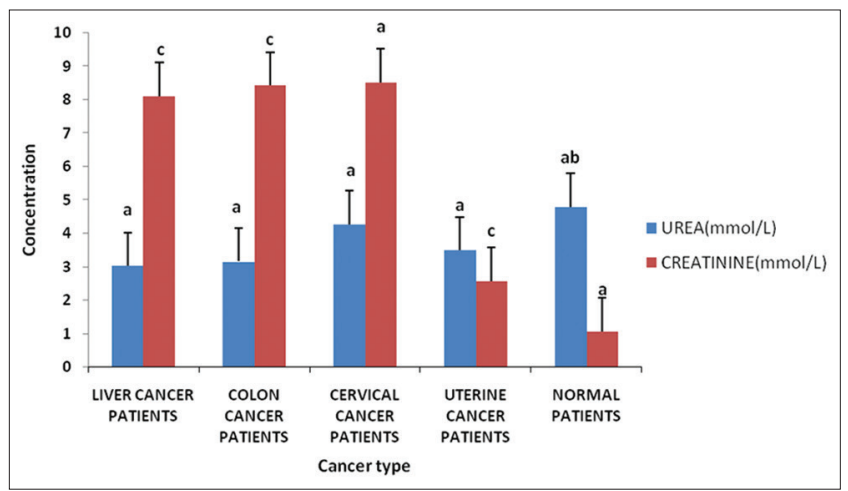

Fig. 2: Concentration of creatinine and urea in the plasma of cancer patients and control subjects. Results were expressed as means \pm standard deviation, $(n=50)$ graphs of the same parameter with different data labels indicate significant difference at $p<0.05$

Table 1: Parameters of blood plasma showing the mean electrolyte levels in liver, colon, cervical, and uterine cancer patients

\begin{tabular}{llllll}
\hline Data of the study & $\begin{array}{l}\text { Liver cancer } \\
\text { patients }\end{array}$ & $\begin{array}{l}\text { Colon cancer } \\
\text { patients }\end{array}$ & $\begin{array}{l}\text { Cervical cancer } \\
\text { patients }\end{array}$ & $\begin{array}{l}\text { Uterine cancer } \\
\text { patients }\end{array}$ & $\begin{array}{l}\text { Normal } \\
\text { patients }\end{array}$ \\
\hline $\mathrm{Na}^{+}(\mathrm{mmol} / \mathrm{L})$ & $141.78 \pm 4.57^{\mathrm{b}}$ & $144.13 \pm 4.16^{\mathrm{b}}$ & $143.35 \pm 3.37^{\mathrm{b}}$ & $143.25 \pm 2.37^{\mathrm{b}}$ & $133.50 \pm 3.02^{\mathrm{a}}$ \\
$\mathrm{K}^{+}(\mathrm{mmol} / \mathrm{L})$ & $4.07 \pm 0.24^{\mathrm{a}}$ & $3.68 \pm 0.21^{\mathrm{a}}$ & $4.10 \pm 0.58^{\mathrm{a}}$ & $3.89 \pm 0.22^{\mathrm{a}}$ & $3.58 \pm 0.29^{\mathrm{a}}$ \\
$\mathrm{Cl}(\mathrm{mmol} / \mathrm{L})$ & $102.72 \pm 3.10^{\mathrm{b}}$ & $101.64 \pm 2.37^{\mathrm{b}}$ & $102.89 \pm 4.67^{\mathrm{b}}$ & $101.85 \pm 1.89^{\mathrm{b}}$ & $97.7 \pm 1.32^{\mathrm{a}}$ \\
$\mathrm{HCO3}^{-}(\mathrm{mmol} / \mathrm{L})$ & $26.18 \pm 2.72^{\mathrm{a}}$ & $24.44 \pm 2.68^{\mathrm{a}}$ & $24.00 \pm 2.26^{\mathrm{a}}$ & $24.36 \pm 3.32^{\mathrm{a}}$ & $25.42 \pm 1.90^{\mathrm{a}}$ \\
\hline
\end{tabular}

Values are given as mean $\pm \mathrm{SD}$, $(\mathrm{n}=50)$ values not showing a common superscript letter differ significantly as $\mathrm{p}<0.05$, SD: Standard deviation 
and the tumor seems to inappropriately metabolize both dietary and host proteins, resulting in the wasting of lean body mass. Tumors may act as nitrogen and energy traps; their growth is preferential to that of the host, this suggests that the enlarging neoplasm is retaining neoplasm while the host tissues are losing it [31-33].

\section{CONCLUSION}

This study revealed a possible association generally between cancer and plasma levels of electrolytes, creatinine, CRP, and urea. This could provide a platform for further research into the diagnosis and management of this disease that is becoming a serious threat to human existence.

\section{REFERENCES}

1. Sylla BS, Wild CP. A million Africans a year dying from cancer by 2030: What can cancer research and control offer to the continent? Int J Cancer 2012;130:245-50.

2. Ferlay J, Shin HR, Bray F, Forman D, Mathers C, Parkin DM. Estimates of worldwide burden of cancer in 2008: GLOBOCAN 2008. Int J Cancer 2010;127:2893-917.

3. Boyle P, Levin B. World Cancer Report 2008. Lyon, France: International Agency for Research on Cancer; 2008

4. Lyerly HK, Abernethy AP, Stockler MR, Koczwara B, Aziz Z, Nair R, et al. Need for global partnership in cancer care: Perceptions of cancer care researchers attending the 2010 Australia and Asia pacific clinical oncology research development workshop. J Oncol Pract 2011;7:324-9.

5. Anand P, Kunnumakkara AB, Kunnumakara AB, Sundaram C, Harikumar KB, Tharakan ST, et al. Cancer is a preventable disease that requires major lifestyle changes. Pharm Res 2008;25:2097-116.

6. Gupta M, Dahiya J, Marwaha RK, Dureja H. Therapies in cancer treatment: An overview. Int J Pharm Pharm Sci 2015;7:1-9.

7. Pramila P, Abraham A, Pawar S, Bafna V, Bansal MS. To study the therapeutic management, drug related problems and concomitant use of drugs in patients with cancer. Int J Pharm Pharm Sci 2017;9:139-44.

8. Yadav AS, Khodke PV. Status of serum electrolytes in cancer patients. Int J Basic Appl Med Sci 2015;5:208-11

9. Jemal A, Bray F, Center MM, Ferlay J, Ward E, Forman D. Global cancer statistics. CA Cancer J Clin 2011;61:69-90.

10. Filippatos TD, Milionis HJ, Elisaf MS. Alterations in electrolyte equilibrium in patients with acute leukemia. Eur $\mathrm{J}$ Haematol 2005;75:449-60.

11. Rosner MH, Dalkin AC. Electrolyte disorders associated with cancer. Adv Chronic Kidney Dis 2014;21:7-17.

12. Salahudeen AK, Ali N, George M, Lahoti A, Palla S. Tolvaptan in hospitalized cancer patients with hyponatremia: A double-blind, randomized, placebo-controlled clinical trial on efficacy and safety. Cancer 2014;120:744-751

13. Carmeliet P. Angiogenesis in health and disease. Nat Med 2003;9:653-60.

14. Gross JL, de Azevedo MJ, Silveiro SP, Canani LH, Caramori ML, Zelmanovitz T. Diabetic nephropathy: Diagnosis, prevention, and treatment. Diabetes Care 2005;28:164-76.
15. Faull R. Prescribing in renal disease. Aust Prescr 2007;30:17-20.

16. Zhang SM, Buring JE, Lee IM, Cook NR, Ridker PM. C-reactive protein levels are not associated with increased risk for colorectal cancer in women. Ann Intern Med 2005;142:425-32.

17. Heikkilä K, Ebrahim S, Rumley A, Lowe G, Lawlor DA. Associations of circulating C-reactive protein and interleukin-6 with survival in women with and without cancer: Findings from the British Women's Heart and Health Study. Cancer Epidemiol Biomarkers Prev 2007;16:1155-9.

18. Suzuki K, Ito Y, Wakai K, Kawado M, Hashimoto S, Seki N, et al. Serum heat shock protein 70 levels and lung cancer risk: A case-control study nested in a large cohort study. Cancer Epidemiol Biomarkers Prev 2006; $15: 1733-7$

19. Siemes C, Visser LE, Coebergh JW, Splinter TA, Witteman JC, Uitterlinden AG, et al. C-reactive protein levels, variation in the C-reactive protein gene, and cancer risk: The Rotterdam Study. J Clin Oncol 2006;24:5216-22.

20. Weatherburn MW. Urease-Berthelot colorimetric method for in vitro determination of urea. Anal Chem S 1967;39:971

21. Bartels H, Böhmer M, Heierli C. Serum creatinine determination without protein precipitation. Clin Chim Acta 1972;37:193-7.

22. AOAC. Official Methods of Analysis. $15^{\text {th }}$ ed. Washington, DC: AOAC; 1990. p. 32-4.

23. Henry RJ, Cannon DC, Winkleman JK. Clinical Chemistry. Maryland, USA: Published by Harger and Row; 1974. p. 248-60.

24. Deraz TE, Kamel TB, El-Kerdany TA, El-Ghazoly HM. Highsensitivity $\mathrm{C}$ reactive protein as a biomarker for grading of childhood asthma in relation to clinical classification, induced sputum cellularity, and spirometry. Pediatr Pulmonol 2012;47:220-5.

25. Kuo HW, Chen SF, Wu CC, Chen DR, Lee JH. Serum and tissue trace elements in patients with breast cancer in Taiwan. Biol Trace Elem Res 2002;89:1-11

26. Milde D, Altmannova K, Vyslouzil K, Stuzka V. Trace element levels in blood serum and colon tissue in colorectal cancer. Clin J 2004;59:157-60.

27. Falconer IS, Slater C, Ross JA, Preston T, Fearon K. Albumin synthetic rates, the acute phase response and cyrolanes in pancreatic cancer. $\mathrm{J}$ Surg 1995;82:682.

28. Sharma J, Gupta S, Soni MM, Malakar M. Pathological outcome in the patients with different ailments: A comprehensive study in Lakhimpur district, Assam. Innov J Med Sci 2014;2:3-5.

29. Koji K, Shiro H, Mitsuo T, Hideyuki A. Serum creatinine level for cervical cancer.Jpn J Oncol 1998;28:546-50.

30. Christy M. Your Own Perfect Medicine. Scottsdale, Arizona: Future Medicine Inc.; 1994. p. 2.

31. Miller DC, Hafez KS, Stewart A, Montie JE, Wei JT, Prostate carcinoma presentation, diagnosis, and staging: An update form the National Cancer Data Base. Cancer 2003;98:1169-78.

32. Saad EA, Habib SA, Refai WA, Elfayoumy AA. Malondialdehyde, adiponectin, nitric oxide, C-reactive protein, tumor necrosis factoralpha and insulin resistance relationships and inter-relationships in Type 2 diabetes early stage. Is metformin alone adequate in this stage? Int J Pharm Pharm Sci 2017;9:176-81.

33. Satayanarayana U, Chakrapani U. Cancer. In: Biochemistry. $4^{\text {th }}$ ed. New York: Books and Allied Publishers Ltd.; 2013. p. 685-94. 